\title{
EVALUASI GOOD CORPORATE GOVERNANCE ATAS KEBUTUHAN DONATUR PADA PENERAPAN CROWDFUNDING DI INDONESIA: STUDI KUANTITATIF DAN KUALITATIF PADA EFEKRUMAHKACA.NET, PATUNGAN.NET, DAN WUJUDKAN.COM
}

\author{
Nia Utami Tirdanatan ${ }^{1}$; Vina Georgiana ${ }^{1}$; Yen Sun ${ }^{2}$ \\ ${ }^{1}$ School of Information Systems, Bina Nusantara University \\ ${ }^{2}$ Accounting and Finance, Bina Nusantara University \\ Jl. K.H. Syahdan No 9, Kemanggisan, Palmerah, Jakarta Barat 11480 \\ melaniautami@yahoo.com,vinageorgiana@binus.edu, ysun@binus.edu
}

\begin{abstract}
This research aims to evaluate the implementation of Good Corporate Governance (GCG) in ensuring the good management of crowdfunding entities in Indonesia. Research methodology is using both quantitative and qualitative approaches. Quantitative approach was conducted by analyzing the factors of the driving forces for donors in financially participating in crowdfunding initiatives. Conceptual framework is developed and a study was conducted to 96 donors from three Indonesian crowdfunding portals. The findings of quantitative study show that the main factor that drive the donors to participate is motivation to accomplish, social merit factors and good trust to the project creator. Based on that results, qualitative study was conducted to evaluate the implementation of Good Corporate Governance (GCG) principles in those three Indonesian crowdfunding portals. The evaluation explains that GCG principles has been well implemented by those administrators of crowdfunding portals. Nevertheless, serious concern should be taken in the area of accountability and financial reporting. The research provides insights for crowdfunding practitioners to be succesfully raise funding and for crowdfunding platforms to be sustainable in this business by implementing good corporate governance. This research takes a further step in explaining crowdfunding phenomenon in Indonesia.
\end{abstract}

Keywords: Crowdfunding, donation, factors, good corporate governance, GCG

\begin{abstract}
ABSTRAK
Penelitian ini bertujuan untuk mengevaluasi penerapan Good Corporate Governance (GCG) dalam menjamin pengelolaan yang sehat pada entitas pengelola crowdfunding di Indonesia. Metodologi penelitian dilakukan dengan menggunakan pendekatan kuantitatif dan kualitatif. Pendekatan kuantitatif dilakukan dengan menganalisis faktor-faktor yang mempengaruhi donatur menyumbang pada crowdfunding. Kerangka konseptual dikembangkan dan studi dilakukan terhadap 96 donatur dari tiga portal crowdfunding di Indonesia. Hasil penelitian kuantitatif menunjukkan bahwa faktor utama yang mempengaruhi donatur menyumbang pada crowdfunding adalah motivasi mewujudkan, faktor sosial/terpuji, dan kepercayaan kepada kreator. Berdasarkan hasil penelitian kuantitatif tersebut, maka dilakukan studi kualitatif dengan mengevaluasi penerapan Good Corporate Governance (GCG) pada ketiga portal crowdfunding di Indonesia. Hasil evaluasi menunjukkan bahwa sebagian prinsip GCG telah diterapkan dengan baik oleh para pengelola portal crowdfunding. Meskipun demikian, perhatian serius perlu diterapkan terutama berkaitan dengan akuntabilitas dan pelaporan keuangan. Penelitian ini memberikan wawasan khususnya bagi pelaku crowdfunding agar sukses menggalang dana melalui crowdfunding dan menjaga keberlangsungan bisnisnya sebagai entitas yang sehat. Penelitian ini juga memberikan gambaran mengenai fenomena crowdfunding di Indonesia.
\end{abstract}

Kata Kunci: Crowdfunding, donasi, faktor, good corporate governance, GCG 


\section{PENDAHULUAN}

Memperoleh dana bukan suatu proses yang mudah. Sebagai contoh, bagaimana cara seorang produser film mengumpulkan biaya produksi untuk sebuah film baru tanpa investor? Bagaimana cara sebuah organisasi nirlaba mengumpulkan dana untuk proyek pemberdayaan masyarakat marjinal? Bagaimana cara seorang wirausaha mendapatkan modal awal (seed capital) untuk membuat sebuah produk inovatif yang baru berupa ide? Secara tradisional, pendanaan bisa diperoleh dengan pinjaman dari bank, lembaga kredit, investor dan angel investor atau melalui venture capital. Sayangnya, instansi-instansi pendanaan tersebut umumnya memiliki mekanisme seleksi proyek yang tidak mudah, terutama bagi proyek-proyek yang belum pasti pengembalian keuntungan seperti proyek seni dan proyek nirlaba. Selain itu, tingkat bunga pinjaman yang tinggi dan adanya kolateral (jaminan) turut memberatkan debitur.

Kondisi ini membuat sebuah gap pendanaan. Pada tahun 2006, seorang ahli eksperimen digital, Michael Sullivan, memberi gagasan untuk menjembatani gap pendanaan tersebut. Sullivan mencetuskan istilah crowdfunding yang mengacu kepada suatu skema pendanaan berbasis khalayak dengan memanfaatkan teknologi web 2.0. Karakteristik utama dari crowdfunding adalah banyak orang memberikan dukungan finansial (umumnya bernominal kecil) untuk suatu proyek melalui website.

Mekanisme crowdfunding diadopsi di Indonesia pada tahun 2012 oleh Patungan.net dan Wujudkan.com, serta pada tahun 2013 oleh EfekRumahKaca.net. Dengan crowdfunding sebagai fenomena Sistem Informasi dan Akuntansi yang baru, maka menjadi penting untuk mengetahui apa saja faktor-faktor yang sesungguhnya memotivasi donatur untuk menyumbang pada crowdfunding serta melakukan evaluasi atas penerapan Good Corporate Governance (GCG) guna menjamin pengelolaan yang sehat pada entitas pengelola crowdfunding. Dengan demikian, terdapat dua pertanyaan yang akan dijawab dalam penelitian ini, yaitu: (1) Apa saja faktor-faktor yang memengaruhi donatur menyumbang pada crowdfunding di Indonesia? (2) Bagaimana penerapan GCG pada entitas pengelola crowdfunding di Indonesia?

\section{Landasan Teori dan Penelitian Terdahulu}

Michael Sullivan mengkonsepkan crowdfunding sebagai mekanisme pendanaan berdasarkan timbal-balik (reciprocity), transparansi, kepentingan bersama (shared-interest) dan, di atas semuanya, berasal dari khalayak masyarakat. Dalam definisi praktis, Canada Media Fund (2012) mendefinisikan crowdfunding sebagai proses penggalangan dana dengan mengumpulkan kontribusi kecil dari masyarakat umum (yaitu crowd) menggunakan internet dan media sosial. Berikut adalah ilustrasi mekanisme umum crowdfunding menurut Hemer (2011):

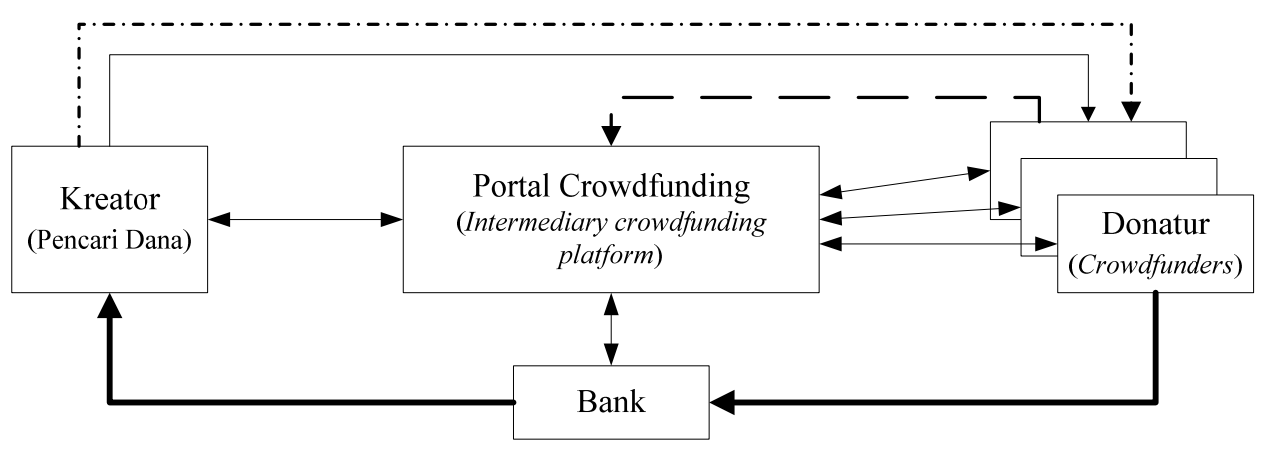

Gambar 1 Mekanisme Umum Crowdfunding 
Keterangan:

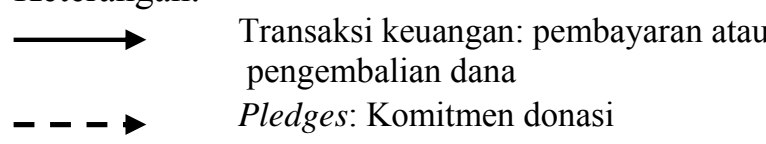

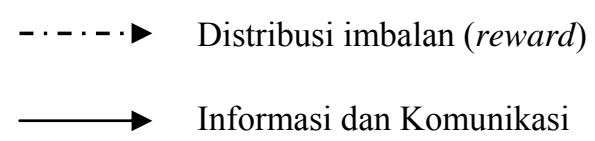

Untuk menganalisis faktor-faktor yang memengaruhi donatur untuk menyumbang pada crowdfunding, penelitian ini mengacu kepada penelitian kualitatif yang dilakukan oleh Ordanini, Miceli, Pizzetti, dan Pasuraman (2011) serta penelitian kuantitatif oleh Berglin dan Strandberg (2013). Meskipun demikian, terdapat perbedaan antara penelitian ini dengan kedua penelitian terdahulu, yaitu pada pendekatan penelitian, lokasi penelitian, serta variabel penelitian. Ordanini et. al. (2011) melakukan penelitian dengan pendekatan kualitatif (wawancara dan observasi) kepada para pengelola portal crowdfunding tanpa melibatkan donatur sedangkan penelitian ini menggunakan kombinasi pendekatan kuantitatif kepada para donatur secara langsung dan pendekatan kualitatif kepada para pengelola portal crowdfunding. Baik penelitian Ordanini et. al. (2011) serta Berglin dan Strandberg (2013) dilakukan di Amerika Serikat sedangkan penelitian ini memilih lokasi di Indonesia. Untuk variabel penelitian, penelitian ini menambahkan dua variabel baru untuk diuji yaitu Inovasi Proyek dan Kualitas proyek. Variabel Inovasi Proyek ditambahkan karena merupakan faktor yang signifikan menurut penelitian Ordanini et. al. (2011) namun tidak signifikan ketika diuji secara kuantitatif oleh Berglin dan Strandberg (2013). Variabel Kualitas Proyek didapatkan dengan melakukan studi eksploratoria awal melalui wawancara kepada pengelola crowdfunding. Dengan adanya penambahan variabel ini, hasil penelitian diharapkan dapat melihat secara lebih luas faktor-faktor yang memotivasi donatur untuk menyumbang dalam crowdfunding.

Menurut Ordanini et. al. (2011), donatur memutuskan untuk menyumbang di proyek crowdfunding karena senang terlibat dalam perilaku inovatif. Tidak seperti model bisnis konvensional yang kebanyakan bertendensi umum (mainstream) dimana produk/jasa yang dijual mengikuti selera pasar dan menguntungkan pemilik modal besar, produk/jasa yang dimuat dalam situs crowdfunding umumnya memiliki konsep yang unik dan berupa ide baru. Dengan demikian, crowdfunding menjadi jembatan bagi para individu yang senang dengan produk-produk inovatif; serta berpeluang menjadi inkubator bagi para kreator inovatif untuk memasarkan karyanya. Dalam penelitian Ordanini et. al. (2011), inovasi produk dinyatakan sebagai faktor utama yang memotivasi donatur untuk menyumbang.

Dalam wawancara dengan Wujudkan.com, Patungan.net, dan EfekRumahKaca.net, dinyatakan bahwa kualitas proyek berpengaruh besar pada pengambilan keputusan donatur untuk menyumbang. Proyek yang terencana dengan baik, berkonsep, dan dapat diimplementasikan (feasible) cenderung berhasil menjaring dana dari masyarakat. Penelitian Ordanini et al. (2011) menyatakan bahwa para donatur termotivasi untuk mendanai suatu proyek karena ingin menjadi bagian dari pemenuhan proyek itu sendiri. Dalam penelitian tersebut, para peneliti mengklaim bahwa umumnya para donatur ingin menjadi bagian dari proyek yang mereka berikan sumbangan. Sedikitnya, mereka merasa sedikit berbela rasa dan bertanggungjawab atas suksesnya sebuah proyek. Penelitian Berglin dan Strandberg (2013) menemukan bahwa variabel willingness to help memiliki median jawaban "sangat setuju" dan being part of making it happen memiliki median "setuju". Keduanya merupakan dua dari tiga faktor yang paling kuat dalam penelitian tersebut.

Pada penelitian Ordanini et al. (2011), dikemukakan bahwa faktor sosial memengaruhi donatur untuk menyumbang pada proyek-proyek crowdfunding. Dikatakan, donatur menggunakan crowdfunding untuk mendukung isu yang menjadi perhatian bersama, terutama isu-isu yang berkaitan dengan kemanusiaan dan isu-isu lingkungan. Penelitian Berglin dan Strandberg (2013) menemukan bahwa variabel contributing to good causes memiliki median jawaban "setuju" dan merupakan salah 
satu dari tiga faktor yang paling kuat (di samping being part of making it happen dan willingness to help yang telah disebutkan di paragraf sebelumnya).

Faktor lainnya yang dianggap memengaruhi donatur menyumbang adalah kepercayaan kepada kreator proyek. Penelitian Berglin dan Strandberg (2013) menemukan bahwa variabel trusting the project founders memiliki median jawaban "setuju". Faktor tersebut menyatakan bahwa donatur mendanai suatu proyek karena mempercayai kreatornya. Penelitian Berglin dan Strandberg (2013) memisahkan variabel trusting the project founders (kepercayaan kepada kreator) dengan variabel personal connection (koneksi personal). Meskipun demikian, penelitian ini menggabungkan koneksi personal sebagai salah satu indikator dari kepercayaan kepada kreator. Hal ini didasarkan pada penelitian Ordanini (2011) yang menyatakan bahwa mereka yang memiliki koneksi personal dengan kreator (misalnya teman, keluarga, rekan kerja, dan sebagainya) merupakan donatur yang menyumbang hingga kira-kira setengah dari target dana tercapai. Apabila dana telah terkumpul, maka timbul kepercayaan dari masyarakat umum untuk turut menyumbang kepada kreator tersebut.

Faktor terakhir yang dianggap memengaruhi donatur menyumbang adalah faktor mengidolakan kreator proyek. Faktor ini menyatakan bahwa donatur menyumbang karena memiliki koneksi psikologis kepada kreatornya, misalnya penggemar atau fans dari yang bersangkutan. Penelitian Ordanini et al. (2011) mengklaim bahwa kurang lebih 50\% dari dana yang terkumpul dari proyek crowdfunding berasal dari lingkaran jaringan (network circle) si kreator itu sendiri. Kreator yang memiliki idola biasanya memiliki komunitas. Komunitas ini sangat berpengaruh, terutama bila aktivitasnya dibagikan melalui jejaring sosial. Dengan demikian, semakin baik jaringan seorang kreator, maka semakin tinggi kecenderungan donatur untuk menyumbang.

\section{Kerangka Konseptual}

Berdasarkan kedua penelitian terdahulu, maka dikembangkan kerangka konseptual untuk menganalisis faktor-faktor yang memengaruhi donatur menyumbang pada crowdfunding, sebagai berikut:

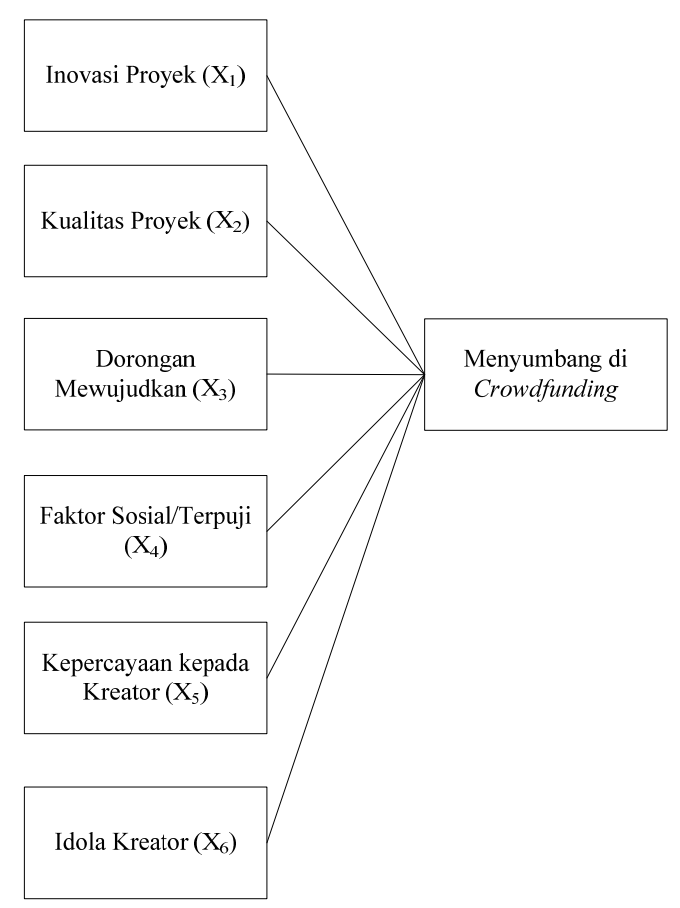

Gambar 2 Kerangka Konseptual Penelitian 
Selanjutnya, berdasarkan temuan atas faktor-faktor yang sesungguhnya memengaruhi donatur, maka diidentifikasi kebutuhan untuk diterapkannya prinsip-prinsip Good Corporate Governance (GCG) oleh entitas pengelola crowdfunding guna menjamin kepercayaan donatur atas pelaksanaan crowdfunding yang bertanggungjawab dan pengelolaan entitas crowdfunding yang sehat. Evaluasi atas GCG dilakukan berdasarkan hipotesis (dugaan sementara) bahwa faktor-faktor yang memengaruhi kecenderungan donatur lebih berupa dorongan psikologis apabila dibandingkan dengan faktor-faktor lain yang lebih objektif seperti kualitas dan inovasi proyek.

Prinsip-prinsip GCG yang akan dianalisis adalah prinsip-prinsip GCG menurut Komite Nasional Kebijakan Governance (2006), yaitu transparansi, akuntabilitas, responsibilitas, independensi, serta kewajaran dan kesetaraan. Transparansi adalah keterbukaan informasi, baik dalam pengambilan keputusan maupun dalam mengungkapkan informasi material dan relevan mengenai perusahaan. Akuntabilitas adalah kejelasan fungsi, struktur, sistem dan pertanggungjawaban organ perusahaan sehingga pengelolaan perusahaan terlaksana secara efektif. Responsibilitas atau pertanggungjawaban adalah kesesuaian dan kepatuhan di dalam pengelolaan perusahaan terhadap prinsip korporasi yang sehat serta peraturan perundangan yang berlaku, termasuk yang berkaitan dengan perpajakan, hubungan industrial, perlindungan lingkungan hidup, kesehatan atau keselamatan kerja, standar penggajian, dan persaingan yang sehat.

Independensi atau kemandirian adalah suatu keadaan ketika perusahaan dikelola secara profesional tanpa benturan kepentingan dan pengaruh atau tekanan dari pihak manapun yang tidak sesuai dengan peraturan perundang-undangan yang berlaku dan prinsip-prinsip korporasi yang sehat. Prinsip terakhir adalah kesetaraan dan kewajaran yang dapat didefinisikan sebagai perlakuan yang adil dan setara dalam memenuhi hak-hak stakeholders yang timbul berdasarkan perjanjian serta peraturan perundangan yang berlaku. Kelima prinsip saling mendukung antara satu dengan lainnya, misalnya akuntabilitas yang merupakan prasyarat pencapaian kinerja yang berkesinambungan tidak dapat ditegakkan tanpa adanya transparansi, akurasi dan reliabilitas informasi yang andal terlebih dahulu. Sedangkan terpenuhinya prinsip responsibilitas merupakan dasar dari prinsip independensi serta kewajaran dan kesetaraan.

\section{METODE}

Metodologi penelitian dikembangkan untuk menjawab dua pertanyaan utama penelitian ini sebagaimana dinyatakan dalam Pendahuluan. Ringkasan metodologi penelitian ditunjukkan oleh Tabel 1 pada halaman selanjutnya.

\section{Metodologi Penelitian Kuantitatif}

Untuk menjawab T-1, yaitu faktor-faktor yang memengaruhi donatur untuk menyumbang pada crowdfunding, maka digunakan pendekatan kuantitatif dengan jenis penelitian Analisis Faktor. Analisis Faktor sendiri merupakan statistik multivariat yang bertujuan untuk meringkas atau mereduksi variabel amatan secara keseluruhan menjadi beberapa variabel atau dimensi baru, namun variabel atau dimensi baru yang terbentuk tetap mampu merepresentasikan variabel utama (Kurniawan dan Yamin, 2009). 
Tabel 1 Metodologi Penelitian

\begin{tabular}{ccllcll}
\hline & $\begin{array}{c}\text { Pendekatan } \\
\text { Penelitian }\end{array}$ & Jenis Penelitian & $\begin{array}{c}\text { Metode } \\
\text { Pengumpulan Data }\end{array}$ & $\begin{array}{c}\text { Unit } \\
\text { Analisis }\end{array}$ & Time Horizon & Lingkungan \\
\hline T-1 & Kuantitatif & $\begin{array}{l}\text { Analisis Faktor } \\
\text { (Factor Analysis) }\end{array}$ & Survei (kuesioner) & Organisasi & Cross-sectional & $\begin{array}{l}\text { Non-contrived } \\
\text { setting }\end{array}$ \\
T-2 & Kualitatif & Eksploratoria & Wawancara, observasi & Organisasi & Cross-sectional & $\begin{array}{l}\text { Non-contrived } \\
\text { setting }\end{array}$ \\
\hline
\end{tabular}

\section{Metode Pengumpulan Data}

Teknik pengumpulan data primer dilakukan dengan metode survei, yaitu dengan menyebarkan pertanyaan tertulis kepada responden dalam bentuk kuesioner online. Kuesioner dapat diakses pada alamat tautan melaniautami.formees.com/f/analisis-faktor-donatur/. Kuesioner online memungkinkan data jawaban dikumpulkan secara langsung kepada peneliti tanpa melalui perantara. Butir-butir pertanyaan dirancang sebagai indikator-indikator yang secara laten mewakili keenam konstrak. Pertanyaan-pertanyaan dalam kuesioner dibuat menggunakan skala Likert 1 sampai dengan 4 untuk mendapatkan rentang jawaban 1 untuk jawaban "Sangat Tidak Setuju", 2 untuk jawaban "Tidak Setuju", 3 untuk jawaban "Setuju", dan 4 untuk jawaban "Sangat Setuju". Skala pengukuran data adalah skala ordinal.

\section{Pemilihan Unit Analisis, Populasi, dan Sampel}

Unit analisis dari penelitian ini adalah organisasi, yakni para portal crowdfunding (crowdfunding platform atau crowdfunding intermediaries) di Indonesia dan para donaturnya. Letak penelitian ini terletak di wilayah DKI Jakarta karena berdasarkan hasil riset meja (desk research) diketahui bahwa mayoritas inisiatif crowdfunding di Indonesia berbasis di Jakarta. Meskipun demikian, crowdfunding dikelola dengan mekanisme online berbasis web, sehingga meskipun portal crowdfunding berbasis di Jakarta, para donatur dapat berasal dari daerah lain di Indonesia (berskala nasional). Atas pertimbangan tersebut, maka organisasi pengelola crowdfunding yang beroperasi di Jakarta telah dipandang representatif untuk mewakili Indonesia. Unit analisis dipilih berdasarkan beberapa kriteria, yaitu crowdfunding memenuhi definisi Lambert/Schwienbacher (2010), terdapat di wilayah DKI Jakarta, dalam keadaan aktif, dan mengizinkan penyebaran kuesioner dan wawancara. Berdasarkan kriteria tersebut, unit analisis yang terpilih adalah EfekRumahKaca.net, Patungan.net, dan Wujudkan.com.

Dari unit analisis terpilih, diketahui bahwa jumlah populasi donatur crowdfunding yang terdata oleh ketiga unit analisis tersebut adalah 2.368 orang. Rumus Taro Yamane pada Riduwan dan Kuncoro (2012) kemudian digunakan karena jumlah populasi $>100$. Dengan menggunakan $\alpha=10 \%$, maka jumlah sampel yang dibutuhkan dalam penelitian ini adalah:

$$
n=\frac{a}{W, \alpha^{2}+1}=\frac{2368}{(2368), 0,1^{2}+1}=\frac{2368}{(2368) \cdot(0,01)+1}=\frac{2368}{24,68}=95.95 \approx 96 \text { responden }
$$

Dimana:

$\mathrm{n}=$ Jumlah sampel $\quad \mathrm{N}=$ Jumlah populasi $\quad \alpha=$ Presisi yang ditetapkan $(1 \%, 5 \%$, atau $10 \%)$

Selanjutnya, ditentukan jumlah sampel dari masing-masing unit analisis menggunakan metode proportionate random sampling. Ringkasan unit analisis terpilih, jumlah populasi, dan jumlah sampelnya ditunjukkan pada Tabel 2. 
Peneliti mengirimkan 1.010 kuesioner online melalui halaman media sosial EfekRumahKaca.net dan Patungan.net, serta melalui kreator Wujudkan.com. Jumlah kuesioner yang kembali adalah 96 dan dengan demikian memiliki response rate sebesar 9,51\%. Saunders, Lewis, dan Thornhill (2012) menyatakan bahwa survei internet pada umumnya memang memiliki response rate kurang dari $11 \%$.

Tabel 2 Unit Analisis Terpilih, Populasi, dan Sampel

\begin{tabular}{lllcc}
\hline No. & \multicolumn{1}{c}{ Nama Pengelola Crowdfunding } & \multicolumn{1}{c}{ Nama Portal } & $\begin{array}{c}\text { Populasi } \\
\text { Donatur }\end{array}$ & Sampel \\
\hline 1. & Yayasan Pikir Buat Nusantara (Aikon) & Patungan.net & 350 & 14 \\
2. & PT. Dukungan Karya Nusantara & Wujudkan.com & 1.500 & 61 \\
3. & Efek Rumah Kaca & EfekRumahKaca.net & 518 & 21 \\
\hline TOTAL & & 2.368 & $\mathbf{9 6}$ \\
\hline
\end{tabular}

\section{Operasionalisasi Variabel}

Pertanyaan pada kuesioner didasarkan pada faktor-faktor dalam kerangka konseptual yang mengacu kepada penelitian terdahulu, yaitu: Inovasi Proyek (IP), Kualitas Proyek (KP), Motivasi Mewujudkan (MM), Sosial terpuji (ST), Kepercayaan kepada Kreator (KK), dan Idola Kreator (IK) sebagai konstrak-konstrak (variabel independen) yang mampu memengaruhi variabel utama (variabel dependen) yaitu motivasi menyumbang pada crowdfunding. Dari enam konstrak tersebut, maka dirancang butir pertanyaan sebagai indikator.

Tabel 3 Operasionalisasi Variabel

\begin{tabular}{llcc}
\hline No. & \multicolumn{1}{c}{ Variabel Independen } & Indikator & Skala Pengukuran \\
\hline 1. & Inovasi Proyek (IP) & 3 pertanyaan & Ordinal \\
2. & Kualitas proyek (KP) & 3 pertanyaan & Ordinal \\
3. & Motivasi Mewujudkan $(\mathrm{MM})$ & 3 pertanyaan & Ordinal \\
4. & Sosial Terpuji (ST) & 3 pertanyaan & Ordinal \\
5. & Kepercayaan kepada Kreator (KK) & 3 pertanyaan & Ordinal \\
6. & Idola Kreator (IK) & 2 pertanyaan & Ordinal \\
\hline No. & $\quad$ Variabel Dependen & Indikator & Skala Pengukuran \\
\hline 1. & Motivasi menyumbang pada crowdfunding $(\mathrm{CF})$ & 1 pertanyaan & Ordinal \\
\hline
\end{tabular}

\section{Analisis Data}

Setelah survei selesai, maka data dikompilasi dan diolah menggunakan software statistik, yaitu software smartPLS untuk melakukan permodelan analisis faktor. Pemilihan analisis Partial Least Square (PLS) dinilai lebih robust untuk analisis faktor dibandingkan dengan analisis regresi yang umum digunakan. PLS adalah model persamaan structural (Structural Equity Modeling atau SEM) dengan pendekatan berbasis varians atau komponen yang berorientasi pada prediksi model. PLS merupakan metode alternatif yang menggeser pendekatan SEM berbasis kovarian (model hubungan kausal sebagaimana regresi) menjadi berbasis varians. Dengan pergeseran pendekatan menjadi berbasis varians inilah, maka model persamaan struktural dengan pendekatan PLS lebih unggul dibandingkan regresi karena dapat menguji bersama-sama model pengukuran (outer model), yaitu hubungan antara masing-masing indikator dengan konstraknya, serta model struktural (inner model), yaitu hubungan antara konstrak dan variabel dependen. Dengan demikian, maka PLS mampu memodelkan hubungan yang bukan saja reflektif (seperti regresi) namun juga yang bersifat formatif. Hubungan formatif artinya bahwa (1) Arah hubungan kausalitas dari indikator menuju konstrak, (2) Diantara indikator diasumsikan tidak saling berkorelasi, (3) Menghilangkan satu indikator berakibat mengubah makna dari konstrak, dan (4) Pengukuran diletakkan pada tingkat konstrak. 
Hal pertama yang dilakukan adalah melakukan perancangan model hipotesis sesuai dengan PLS yang terdiri atas perancangan model struktural dan model pengukuran. Setelah melakukan permodelan hipotesis, maka secara otomatis software smartPLS melakukan konversi diagram jalur ke persamaan dan perdugaan parameter (weight estimate) untuk menghitung data variabel laten. Selanjutnya dilakukan pertama, Evaluasi Model Pengukuran (outer model), yang terdiri dari (a) Pengujian validitas konvergen (convergent validity); pengujian ini bertujuan untuk menilai seberapa valid indikator-indikator (yaitu item-item pertanyaan dalam kuesioner) mengukur sebuah konstrak. Validitas dilihat dari nilai faktor loading dan nilai $t_{\text {statistik }}$. (b) Pengujian validitas diskriminan (discriminant validity). (c) Pengujian reliabilitas komposit (composite reliability). Kedua, Evaluasi Model Struktural (inner model), yaitu pengujian atas nilai $R$-Square $\left(\mathrm{R}^{2}\right)$. Ketiga, dilakukan pengujian hipotesis dimana $\mathrm{H}_{0}$ diterima bila nilai $\mathrm{t}_{\text {statistik }}<\mathrm{t}_{\text {tabel }}$ dan sebaliknya Ha diterima bila $\mathrm{t}_{\text {statistik }}>\mathrm{t}_{\text {tabel }}$.

\section{Metodologi Penelitian Kualitatif}

Untuk menjawab T-2, yaitu penerapan GCG pada entitas pengelola crowdfunding di Indonesia, maka digunakan pendekatan kualitatif yang bersifat basis kasus (case-based). Pendekatan tersebut memfasilitasi suatu penelitian untuk mengeksplorasi suatu fenomena pada konteksnya. Yin (2003) menyatakan bahwa pendekatan kualitatif basis kasus terutama cocok untuk menjawab pertanyaan penelitian "bagaimana" dan "mengapa". Penggunaan pendekatan ini semakin tepat bila tujuan penelitian adalah untuk memperoleh pemahaman yang mendalam mengenai suatu fenomena baru dimana konsep dan konteks dari objek yang diteliti sangat terbatas, misalnya kurangnya penelitian terdahulu mengenai fenomena tersebut atau - kalaupun ada - area pembahasannya sangat terbatas.

\section{Metode Pengumpulan Data}

Pengumpulan data untuk penelitian kualitatif dilakukan dengan melakukan wawancara kepada pengelola crowdfunding dari unit analisis terpilih dan observasi langsung yaitu EfekRumahKaca.net, Patungan.net, dan Wujudkan.com. Data primer diperoleh melalui wawancara. Wawancara dilakukan sebanyak empat kali (rincian dapat dilihat pada Tabel 4) di mana pertanyaan disiapkan sebelum wawancara dilakukan. Selain melalui wawancara tatap-muka, korespondensi melalui email dilakukan secara aktif untuk memverifikasi temuan-temuan yang ditemukan pada saat observasi.

Tabel 4 Rincian Wawancara

\begin{tabular}{lrl}
\hline \multicolumn{1}{c}{ Nama Portal } & Tanggal & \multicolumn{1}{c}{ Narasumber } \\
\hline EfekRumahKaca.net & 24 Mei 2013 & $\begin{array}{l}\text { Personil Efek Rumah Kaca, Manajer, Staf pemasaran dan media } \\
\text { sosial crowdfunding, serta Personil Pandai Besi }\end{array}$ \\
Wujudkan.com & 31 Mei 2013 & CEO dan Manajer Operasional \\
Wujudkan.com & 13 Juni 2013 & Komisaris \\
Patungan.net & 20 Juni 2013 & Koordinator Patungan.net \\
\hline
\end{tabular}

Metode pengumpulan yang juga dilakukan adalah observasi. Observasi adalah kegiatan memperhatikan secara akurat, mencatat fenomena yang muncul, dan mempertimbangkan hubungan antara aspek dalam fenomena tersebut (Riduwan dan Kuncoro, 2012). Observasi dilakukan penulis dengan turut serta menjadi donatur pada ketiga portal crowdfunding yang menjadi objek penelitian. Keterlibatan tersebut bertujuan untuk memeroleh pespektif yang menyeluruh terhadap kegiatan crowdfunding yang dilakukan EfekRumahKaca.net, Patungan.net, dan Wujudkan.com. Dari observasi diperoleh data sekunder berupa informasi dari situs crowdfunding, laporan pers (press reports) dan publikasi lainnya. 


\section{Analisis Data}

Analisis data dilakukan melalui tiga tahap, yaitu coding, categorizing, dan comparing. Dalam coding, dilakukan pemecahan (breaking down) data wawancara menjadi unit interpretasi. Ketika melakukan wawancara, peneliti mencatat catatan jawaban narasumber. Dengan demikian, pada tahap coding dilakukan pembacaan kembali atas catatan tersebut untuk memperoleh pemahaman atas jawaban narasumber. Selanjutnya dilakukan categorizing dimana unit interpretasi tadi dikelompokkan menjadi kategori-kategori yang bermakna (meaningful categories). Jawaban dikelompokkan secara umum kepada prinsip-prinsip GCG yang sesuai dan secara spesifik kepada indikator-indikator dari suatu prinsip. Setelah coding dan categorizing dilakukan, maka hasil dari satu entitas dengan entitas lainnya dibandingkan.

\section{HASIL DAN PEMBAHASAN}

\section{Penelitian Kuantitatif}

Dari 96 kuesioner valid yang diolah, terdapat 58,3\% responden laki-laki dan 41,7\% responden perempuan. Kelompok usia responden adalah 18 tahun ke bawah (2,1\%), 18-24 tahun (51\%), 25-34 tahun $(31,2 \%), 35-54$ tahun $(15,6 \%)$, dan 55 tahun ke atas (0\%). Statistik deskriptif pekerjaan dari para responden yaitu pelajar/mahasiswa $(34,4 \%)$, karyawan swasta $(29,2 \%)$, pekerja seni $(11,5 \%)$, Selain ketiga pekerjaan tersebut, maka tercatat persentase dibawah $10 \%$ yakni pegawai negeri sipil $(6,2 \%)$, pekerja media $(3,1 \%)$, pengajar $(4,2 \%)$, profesional $(4,2 \%)$, wirausahawan $(3,1 \%)$ dan lainnya $(4,2 \%)$.

Secara khusus, penelitian ini juga memperoleh informasi dari responden terkait dengan donasi yang pernah dilakukan pada crowdfunding, yaitu jumlah proyek crowdfunding yang pernah didukung dan total donasi yang diberikan. Lebih dari separuh responden baru pernah menyumbang pada satu proyek crowdfunding $(63,5 \%)$. Sebanyak $32,3 \%$ responden telah menyumbang pada $2-5$ proyek crowdfunding, 2,1\% responden telah menyumbang kepada 6-10 proyek, dan 2,1\% responden telah menyumbang sebanyak lebih dari 10 proyek crowdfunding. Besaran donasi yang diberikan (dalam Rupiah) adalah dibawah 100 ribu (12,5\%), 100-500 ribu (72,9\%), 500 ribu-1 juta (6,2\%), 1-5 juta $(7,3 \%)$, dan diatas 5 juta $(1 \%)$.

Permodelan penelitian dengan menggunakan software smartPLS digambarkan sebagaimana Gambar 3 di bawah ini:

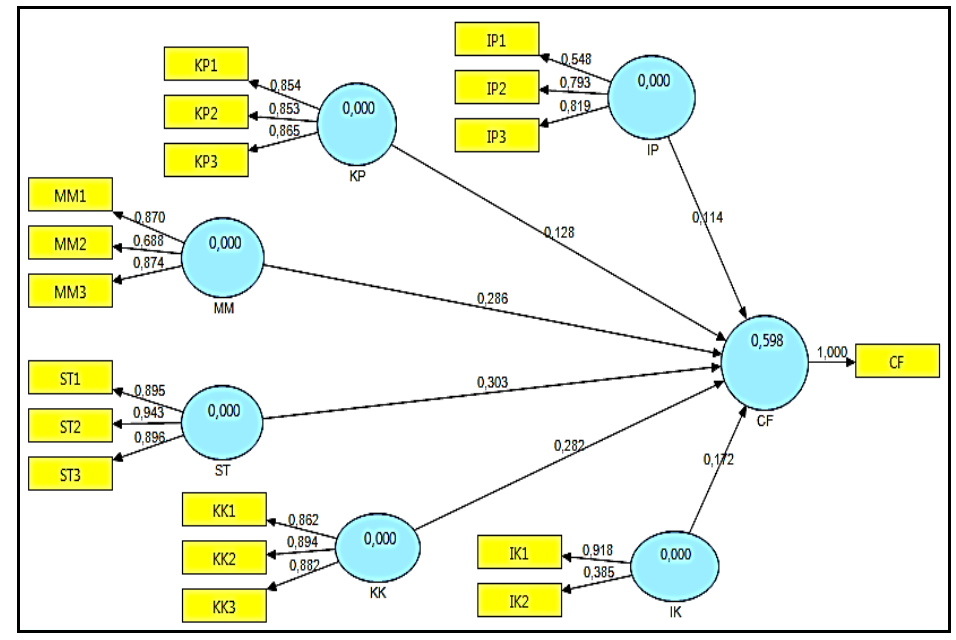

Gambar 3 Model Penelitian Awal (Pra-Eliminasi) 
Dari hasil pengujian validitas konvergen, ditemukan bahwa nilai IK2, IP1, dan MM2 tidak valid untuk menggambarkan masing-masing konstraknya sehingga ketiganya harus dieliminasi dari model. Dengan dieliminasinya ketiga indikator yang tidak valid, maka dilakukan kembali pengujian terhadap model yang baru mengingat sifat formatif PLS yaitu menghilangkan suatu indikator berakibat mengubah makna dari konstrak. Dengan demikian, eliminasi yang dilakukan terhadap indikator dapat berdampak pada validitas indikator lainnya. Model penelitian pasca-eliminasi dapat dilihat pada Gambar 4:

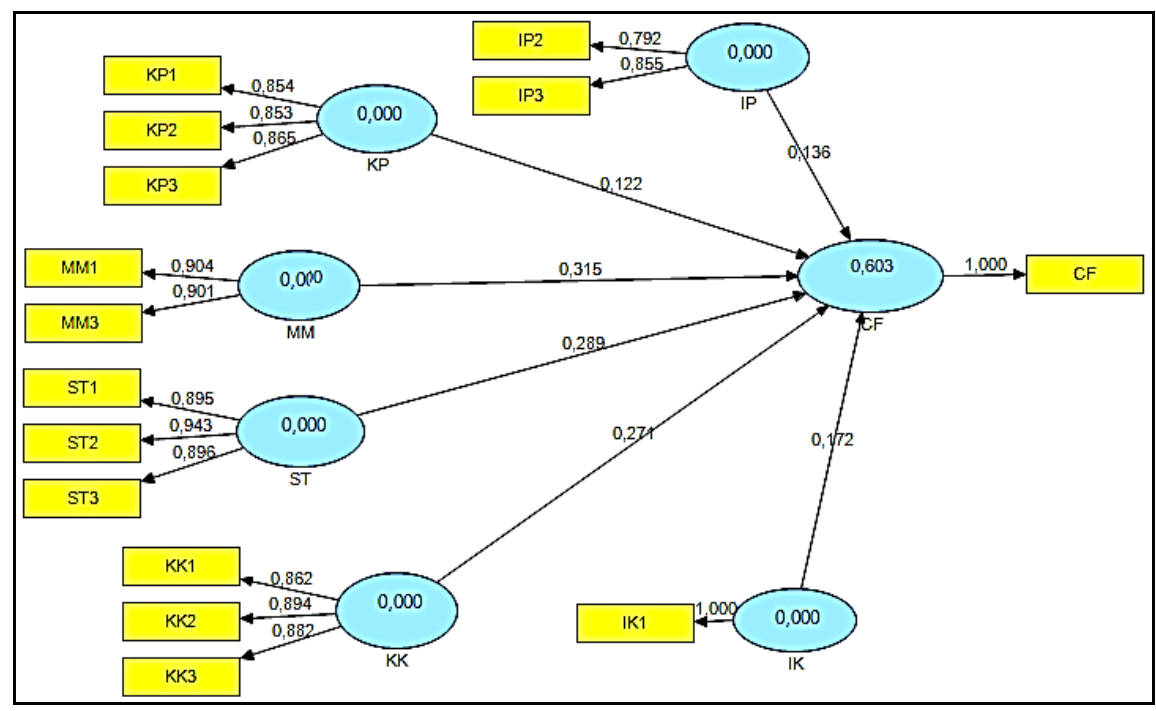

Gambar 4 Model Penelitian (Pasca-Eliminasi)

Hasil pengujian validitas konvergen pada model penelitian yang baru menunjukkan bahwa keseluruhan indikator adalah valid, terlihat dari nilai t-statistik dari semua indikator lebih besar dari 1,96 dan nilai faktor loading lebih besar dari 0,7. Dengan demikian, validitas konvergen terpenuhi. Selanjutnya, model penelitian menunjukkan bahwa nilai cross loading dari setiap konstrak laten memprediksi indikatornya lebih baik daripada konstrak lainnya. Hal ini menjadi dasar untuk mengevaluasi nilai average value extracted (AVE) dan akar AVE tersebut. Kurniawan dan Yamin (2009) merekomendasikan nilai AVE > 0,5 dan nilai akar AVE > nilai korelasi antar konstrak. Dari pengujian, ditemukan bahwa kedua persyaratan terpenuhi dan dengan demikian validitas diskriminan yang baik tercapai.

Setelah pengujian validitas, maka dilakukan pengujian reliabilitas untuk menguji apakah pelaksanaan pengukuran mempunyai konsistensi pengukuran yang baik. Hasil uji reliabilitas setiap konstrak penelitian ini memiliki nilai keterandalan $>0,8$. Hasil tersebut menandakan internal consistency yang tinggi dari variabel dependen (CF) dengan variabel independennya (IK, IP, KK, KP, $\mathrm{MM}, \mathrm{ST}$ ) sehingga dapat dikatakan bahwa konstrak memiliki reliabilitas yang baik. Dengan telah terpenuhinya validitas konvergen, validitas diskriminan, dan reliabilitas komposit, dapat disimpulkan bahwa model pengukuran (outer model) dalam penelitian ini andal untuk dilakukan analisis faktor.

Analisis faktor melibatkan evaluasi model struktural (inner model) dengan mencari koefisien jalur. Pengujian terhadap model penelitian menghasilkan nilai original sample yang semuanya positif untuk setiap konstrak. Dengan demikian, tidak ditemukan adanya korelasi negatif antara konstrak dengan variabel dependen. Signifikansi pengaruh terlihat dari nilai t-statistik. Pengaruh positif signifikan didapatkan bila nilai t-statistik $>1,96$ sedangkan pengaruh positif non-signifikan didapatkan bila nilai t-statistik $<1,96$. Diketahui bahwa konstrak MM, ST, dan KK memiliki pengaruh positif signifikan sedangkan konstrak KP, IP, dan IK memiliki pengaruh positif non-signifikan. 
Langkah terakhir adalah mencari variabilitas keseluruhan konstrak ("faktor") untuk memengaruhi donatur dalam memberikan sumbangan. Variabilitas diketahui dengan melihat nilai RSquare $\left(\mathrm{R}^{2}\right)$, yaitu sebesar 0,6026 . Hal ini dapat diinterpetasikan sebagai variabilitas faktor-faktor IP, KP, MM, ST, KK, dan IK memotivasi responden menyumbang pada crowdfunding sebesar $60,26 \%$. Variabilitas sisanya, yaitu sebesar $39,74 \%$ lainnya dijelaskan oleh variabel lain di luar model penelitian.

\section{Faktor-Faktor yang Mempengaruhi Donatur Menyumbang pada Crowdfunding}

Penelitian menemukan faktor-faktor yang secara positif memengaruhi donatur untuk menyumbang pada crowdfunding dengan tiga diantaranya memiliki signifikansi yang besar dibandingkan sisanya. Ketiga faktor tersebut adalah: Motivasi Mewujudkan, Sosial Terpuji, dan Kepercayaan kepada Kreator. Faktor sisanya yang juga berpengaruh positif namun kurang signifikan adalah Inovasi Proyek, Kualitas Proyek, dan Idola Kreator.

Motivasi Mewujudkan memiliki nilai signifikansi tertinggi, terlihat dari nilai original sample estimate $(\mathrm{OSE})=0,3146$ dan nilai t-statistik $=5,11$ (lebih besar daripada nilai t-tabel $=1,96)$. Hasil ini mendukung hasil penelitian Ordanini et. al. (2011) yang menyatakan bahwa donatur termotivasi untuk menyumbang karena berkeinginan untuk membantu serta menjadi bagian dari kesuksesan suatu proyek. Faktor dengan signifikansi tertinggi kedua adalah faktor Sosial Terpuji, terlihat dari nilai OSE $=0,2889$ dan nilai t-statistik $=4,09$. Hasil ini kembali mendukung hasil penelitian Ordanini et. al. (2011) yang menyatakan bahwa kebanyakan donatur termotivasi untuk menyumbang proyek-proyek crowdfunding yang mengedepankan isu-isu yang menjadi perhatian bersama, misalnya isu kemanusiaan atau lingkungan.

Faktor dengan signifikansi tertinggi ketiga adalah faktor Kepercayaan kepada Kreator, terlihat dari nilai $\mathrm{OSE}=0,2708$ dan nilai t-statistik $=3,19$. Hasil ini sejalan dengan penelitian Berglin dan Strandberg (2013) yang menemukan kepercayaan sebagai salah satu faktor utama yang memotivasi donatur untuk menyumbang pada crowdfunding. Menjadi menarik untuk menyimpulkan bahwa temuan penelitian ini memiliki konsistensi yang tinggi dengan hasil penelitian terdahulu dan dengan demikian mengisyaratkan bahwa donatur tidak sepenuhnya melihat kontribusi mereka sebagai "pure purchase" ataupun investasi melainkan kemungkinan untuk membantu, kontribusi kepada isu sosial terpuji, dan wujud dukungan terhadap seorang kreator yang mereka percayai.

Tidak signifikannya tiga faktor lainnya, yakni Kualitas Proyek, Inovasi Proyek, dan Idola Kreator menimbulkan diskusi yang menarik. Implikasinya, entitas pengelola crowdfunding di Indonesia perlu sedikit 'menggeser' perhatian untuk tidak melulu berfokus kepada seleksi proyek melainkan memperhatikan, menjaga, dan memperbesar kepercayaan masyarakat terhadap entitas crowdfunding itu sendiri. Salah satu caranya adalah dengan memastikan penerapan tata kelola perusahaan yang baik sebagaimana dinyatakan dalam prinsip-prinsip GCG.

\section{Penelitian Kualitatif}

Dari wawancara dan observasi yang dilakukan, ditemukan bahwa penerapan GCG pada EfekRumahKaca.net, Patungan.net, dan Wujudkan.com belum maksimal. Perlu diketahui, ketiga portal crowdfunding memiliki bentuk hukum yang berbeda: Patungan.net berbentuk yayasan, Wujudkan.com berbentuk perseroan terbatas (PT), dan EfekRumahKaca adalah kelompok band. Dengan demikian, terdapat perbedaan perlakuan dan dasar hukum dalam melihat kesesuaian penerapan GCG pada ketiga entitas tersebut. Patungan.net perlu tunduk terutama kepada UndangUndang No. 28 Tahun 2004 tentang Yayasan dan Wujudkan.com terutama tunduk pada UndangUndang Perseroan Terbatas dan Ketentuan Umum Perpajakan. EfekRumahKaca.net mendapat perlakuan khusus mengingat bentuk crowdfundingnya adalah pre-selling sehingga hak dan kewajibannya cenderung terbatas pada terpenuhinya hak "pembeli" (yaitu donatur) dan "penjual" (yaitu EfekRumahKaca). Ringkasan hasil penelitian kualitatif dapat dilihat pada Tabel 5. 
Dari tabel tersebut terlihat bahwa beberapa area telah memenuhi prinsip penerapan GCG yang baik namun masih terdapat pula area-area yang perlu dibenahi, khususnya berkaitan dengan prinsip transparansi dan akuntabilitas. Belum maksimalnya penerapan prinsip transparansi dan akuntabilitas disebabkan oleh skala entitas pengelola crowdfunding yang relatif kecil dimana belum adanya pemisahan wewenang, tugas, dan tanggung jawab yang jelas antara pemilik dan manajemen. Pada Patungan.net, misalnya, hanya terdapat satu orang koordinator yang dibantu oleh bendahara Yayasan dan staf pemasaran. Pada Wujudkan.com pemisahan tugas lebih baik dimana terdapat komisaris, direksi, dan staf. Sayangnya, komisaris masih terlibat secara langsung pada tingkat operasional. Pada kasus EfekRumahKaca.net, proyek crowdfunding dikerjakan dengan basis kekeluargaan. Situasi seperti ini jelas menyulitkan penerapan prinsip akuntabilitas yang kemudian berimplikasi pada tidak terpenuhinya persyaratan dari prinsip transparansi seperti laporan keuangan tahunan. Akuntabilitas yang rendah juga berpotensi mengganggu independensi dimana seharusnya setiap entitas memiliki organ pengawas independen. Meskipun demikian, crowdfunding memberikan wewenang khusus kepada masyarakat umum untuk bertindak sebagai organ pengawas. Adapun penerapan kedua prinsip lainnya yakni responsibilitas, serta kewajaran dan kesetaraan telah dilakukan dengan baik oleh para entitas pengelola crowdfunding.

Tabel 5 Evaluasi Penerapan GCG

\begin{tabular}{|c|c|c|}
\hline Patungan.net & Wujudkan.com & EfekRumahKaca.net \\
\hline \multicolumn{3}{|l|}{ 1. Prinsip Transparansi } \\
\hline $\begin{array}{l}\text { Aktivitas dan arus donasi disampaikan secara } \\
\text { transparan pada situs }\end{array}$ & $\begin{array}{l}\text { Aktivitas dan arus donasi disampaikan secara } \\
\text { transparan pada situs }\end{array}$ & $\begin{array}{l}\text { Aktivitas dan arus donasi disampaikan } \\
\text { secara transparan pada situs }\end{array}$ \\
\hline Identitas kreator belum terstandarisasi & $\begin{array}{l}\text { Tidak menginformasikan estimasi waktu } \\
\text { pengantaran reward }\end{array}$ & $\begin{array}{l}\text { Estimasi pengantaran reward } \\
\text { dikomunikasikan dengan baik. }\end{array}$ \\
\hline Tidak menerbitkan laporan tahunan sesuai dengan & Tidak menyelenggarakan pembukuan sesuai & Belum menerbitkan laporan \\
\hline $\begin{array}{l}\text { Undang-Undang No. } 28 \text { Tahun } 2004 \text { Pasal } 54 \text { ayat (1) - } \\
\text { tentang Yayasan }\end{array}$ & $\begin{array}{l}\text { dengan SAK ETAP paragraf } 3.12 \text { sebagaimana } \\
\text { disyaratkan oleh -Undang-Undang KUP No. } 36 \\
\text { Thn. } 2008 \text { pasal } 28 \text { ayat ( } 7 \text { ) }\end{array}$ & $\begin{array}{l}\text { penggunaan dana (sedang } \\
\text { direncanakan) }\end{array}$ \\
\hline \multicolumn{3}{|l|}{ 2. Prinsip Akuntabilitas } \\
\hline $\begin{array}{l}\text { Akuntabilitas proses dan akuntabilitas program } \\
\text { dilaksanakan dengan baik }\end{array}$ & $\begin{array}{l}\text { Akuntabilitas proses, akuntabilitas program, dan } \\
\text { akuntabilitas kebijakan dilaksanakan dengan baik }\end{array}$ & - \\
\hline Pengendalian internal tidak sesuai dengan UU No. 28 & Pengendalian internal yang lemah (mengacu pada & \\
\hline Tahun 2004 Pasal 36 ayat (2) & PSA No. 69 Seksi 319) & \\
\hline $\begin{array}{l}\text { Tidak adanya AD/ART sebagai pedoman code of } \\
\text { conduct }\end{array}$ & $\begin{array}{l}\text { Tidak melakukan audit laporan keuangan sesuai } \\
\text { PSA No. } 58(710)\end{array}$ & \\
\hline Aktivitas crowdfunding legal sesuai dengan UU No. 28 & Aktivitas crowdfunding legal sesuai dengan & Bertanggungjawab penuh terhadap \\
\hline Tahun 2004 pasal 3 ayat (1) & $\begin{array}{l}\text { Peraturan Menteri Perdagangan No. 36/M- } \\
\text { DAG/PER/9/2007 }\end{array}$ & $\begin{array}{l}\text { penyelesaian proyek, pengantaran } \\
\text { hingga ke tangan donatur, dan }\end{array}$ \\
\hline Good corporate citizen & Good corporate citizen & menjamin kualitas produk yang \\
\hline $\begin{array}{l}\text { Aktivitas crowdfunding dilakukan secara hati-hati dan } \\
\text { melibatkan seleksi yang memadai }\end{array}$ & $\begin{array}{l}\text { Aktivitas crowdfunding dilakukan secara hati-hati } \\
\text { dan melibatkan seleksi yang memadai }\end{array}$ & dikirimkan \\
\hline \multicolumn{3}{|l|}{ 4. Prinsip Independensi } \\
\hline $\begin{array}{l}\text { Tidak mengizinkan "komersialisasi" oleh donatur } \\
\text { (mengiklankan pribadi/organisasi tertentu karena } \\
\text { menjadi donatur suatu proyek tertentu) }\end{array}$ & $\begin{array}{l}\text { Tidak ditemukan benturan kepentingan dari pihak } \\
\text { eksternal maupun internal }\end{array}$ & - \\
\hline Tidak menerima proyek partai politik & Dewan Komisaris bertindak secara aktif dalam & \\
\hline $\begin{array}{l}\text { Tidak memiliki organ pengawas formal (pengawasan } \\
\text { dilakukan oleh Dewan Pembina) } \rightarrow \text { Publik }\end{array}$ & $\begin{array}{l}\text { kegiatan operasional perusahaan, terutama dalam } \\
\text { bidang keuangan sehingga berpotensi mengurangi } \\
\text { independensi. }\end{array}$ & \\
\hline \multicolumn{3}{|l|}{ 5. Prinsip Kewajaran dan Kesetaraan } \\
\hline $\begin{array}{l}\text { Secara operasional telah menerapkan prinsip kewajaran } \\
\text { dan kesetaraan, terhadap: } \\
\text { - } \quad \text { Pengguna situs } \\
\text { - } \quad \text { Donatur } \\
\text { - } \quad \text { Kreator } \\
\text { - } \quad \text { Anggota }\end{array}$ & $\begin{array}{l}\text { Secara operasional telah menerapkan prinsip } \\
\text { kewajaran dan kesetaraan, terhadap: } \\
\text { - } \quad \text { Pengguna situs } \\
\text { - } \quad \text { Donatur } \\
\text { - } \quad \text { Kreator } \\
\text { - } \quad \text { Pola Karir }\end{array}$ & $\begin{array}{l}\text { Semua donatur diberikan hak imbalan } \\
\text { sesuai dengan donasi yang diberikan } \\
\text { pada waktu yang telah diinformasikan } \\
\text { sejak awal. }\end{array}$ \\
\hline $\begin{array}{l}\text { Tidak adanya kebijakan tertulis mengenai hak dan } \\
\text { kewajiban para pengguna situs } \\
\text { Donatur perusahaan (corporate donors) memperoleh } \\
\text { perlakuan yang setara dengan donatur individual: } \\
\text { - } \quad \text { tidak diperbolehkan memasang iklan pada situs; } \\
\text { - } \quad \text { reward sesuai dengan list }\end{array}$ & $\begin{array}{l}\text { Memiliki kebijakan tertulis yang lengkap } \\
\text { mengenai hak dan kewajiban para pengguna situs }\end{array}$ & \\
\hline
\end{tabular}




\section{SIMPULAN}

Dari penelitian kuantitatif didapatkan bahwa faktor yang berpengaruh positif signifikan dalam memengaruhi donatur menyumbang pada crowdfunding adalah Motivasi Mewujudkan, Sosial Terpuji, dan Kepercayaan Kepada Kreator. Faktor yang berpengaruh positif namun non-signifikan dalam memengaruhi donatur menyumbang pada crowdfunding adalah Idola Kreator, Inovasi proyek, dan Kualitas Proyek. Kualitas proyek, inovasi proyek, motivasi mewujudkan, sosial terpuji, kepercayaan kepada kreator dan idola kreator memotivasi responden menyumbang pada crowdfunding sebesar $60,26 \%$. Pengaruh sebesar 39,74\% lainnya dijelaskan oleh faktor lain di luar model penelitian. Sedangkan kesimpulan dari penelitian kualitatif adalah pengelola crowdfunding di Indonesia belum sepenuhnya menerapkan GCG dikarenakan skala organisasinya yang kecil sehingga menyulitkan terciptanya kejelasan fungsi, tugas, dan wewenang karyawan yang pada akhirnya memengaruhi akuntabilitas dan transparansi dalam pengelolaan crowdfunding. Patungan.ne berada di bawah naungan Yayasan Pikir Buat Nusantara, hal ini bertentangan dengan Undang-undang Nomor 28 Tahun 2004 Pasal 54 ayat 1 dan Wujudkan.com yang berbentuk Perseroan Terbatas, pencatatan akuntansi tidak sesuai dengan SAK-ETAP. Prinsip responsibilitas serta kewajaran dan kesetaraan telah diterapkan dengan baik oleh para pengelola crowdfunding. Secara struktural, penerapan prinsip independensi pada pengelola crowdfunding kurang maksimal karena tidak memiliki organ pengawas yang independen. Meskipun demikian, masyarakat secara khusus diberikan wewenang sebagai organ pengawas. Dalam pelaksanaannya para pengelola crowdfunding dikelola secara profesional tanpa benturan kepentingan dan tekanan dari pihak luar.

\section{DAFTAR PUSTAKA}

Canada Media Fund. (2012). Crowdfunding in a Canadian Context: Exploring the Potential of Crowdfunding in the Creative Content Industries. Toronto: CMF Publication.

Hemer, Joachim. (2011). A Snapshot on Crowdfunding. Karlsruhe, Jerman: Working Papers Firms and Region, Fraunhover Institute for System and Innovation Research ISI.

Ordanini, A., Miceli, 1., Pizzetti, M., Parasuraman, A. (2011). Crowdfunding: Transforming Customers Into Investors Through Innovative Service Platforms. Emerald Journal of Service Management, 22(4).

Berglin, Henrik, Strandberg, C. (2013). Leveraging Customers As Investors: The Driving Forces Behind Crowdfunding. Tesis tidak dipublikasikan: Uppsala University, Swedia.

Komite Nasional Kebijakan Governance. (2006). Pedoman Umum Good Corporate Governance Indonesia, diakses dari: http://www.ecgi.org/codes/documents/indonesia_cg_2006 id.pdf.

Kurniawan, Heri, Yamin, S. (2009). Structural Equation Modeling Belajar Lebih Mudah Teknik Analisis Data Kuesioner dengan Lisrel - PLS. Jakarta: Salemba Infotek.

Lambert, T. dan A. Schwienbacher. (2010). An Empirical Analysis of Crowdfunding, diakses dari http://ssrn.com/abstract $=1578175$.

Riduwan dan Engkos Achmad Kuncoro. (2012). Cara Menggunakan dan Memaknai Analisis Jalur (Path Analysis). Bandung: Alfabeta.

Saunders, M., P. Lewis, Thornhill, A. (2012). Research Methods for Business Students. Harlow: Pearson.

Yin, R. K. (2003). Case Study Research: Design and Methods. $3^{\text {rd }}$ ed., Applied Social Research Methods Series, Vol. 5. Thousand Oaks, CA: Sage. 